Nuances of individual lecturers and its impact on

students' information behaviour and creativity
Information Impact:

Journal of Information and

Knowledge Management

2016, Vol. 7 (2) Pg 1 - 14

ISSN: $2141-4297$ (print)

ISSN: $2360-994 X$ (e-version)

Dorcas Ejemeh Krubu

Ambrose Alli University, Nigeria

\begin{abstract}
The paper reveals one of the themes that emerged from a research work at the University of the Western Cape, South Africa. The research was on the information behavior of Nigerian undergraduates in the world of Web 2.0, using a specialized university as a case study. Of the themes that emerged, of interest in this paper are the nuances of individual lecturers and its impact on students' information behavior and creativity. The research work employed mixed methods of qualitative and quantitative research. However, the aspect of data gathering that revealed the essence of this article are dialogue journaling on WhatsApp Messenger with 77 third year students of petroleum engineering department on group assignments and large group discussions with 15 of the 77 students. Kuhlthau's Information Search Process (ISP) Model was employed as a lens in studying the student's information behavior in the process of writing assignment while Blooms Taxonomy was used to rank the assignment as either Lower Order Thinking Skills (LOTS) or Higher Order Thinking Skills (HOTS). The assignment was ranked LOTS because students were requested to read and summarize certain chapters of a textbook. The time allotted for the group assignment was about a week which did not give room for students to collaborate effectively, thereby undermining the pedagogy of group assignment. Due to the poor conduct of the assignment, students did not seem to conform to the Kuhthau's ISP model. Also, students expressed how some lecturers expect them to regurgitate what they have been thought without giving room for individual language, expression, and creativity, hence inhibiting their ISP process. Rather than employing Kuhlthau's ISP model to explore students information seeking process, the research recommends Theory of Change by Quality Education in Developing Countries (QEDC) (2008) and the theory and practice of critical education by Shor (2012).
\end{abstract}

Keywords: Nuances of lecturers, Information behavior, creativity, Kuhlthau's ISP model, Theory of Change

\title{
Introduction
}

The research paper details one of the themes that emerged from a research work on the information behavior of Nigerian undergraduates in the world of Web 2.0, using a specialized university as a case study. The fundamental question the study sought to explore was whether the Nigerian undergraduates have the ability and essential skills to use resources available in the $21^{\text {st }}$ century for self-development and academic excellence. The key concern was to know how undergraduates interact with information, irrespective of the context, either digital or print. 
It is crucial to note that as Information and Communications Technologies (ICTs) are fast evolving, information handling competencies, including computer and Web literacy skills, of undergraduates are increasingly becoming issues of urgent concern in the context of Nigerian higher education and Nigeria's vision of becoming one of the largest 20 economies in the world by the year 2020. Nigeria Vision 20:2020 (NV20:2020) is a national policy objective designed to drive the country up to the league of top 20 economies by 2020 . The two broad objectives of NV20:2020 is to channel human and natural resources to achieve rapid economic growth; and translate the economic growth into equitable social development for all citizens (National Planning Commission (NPC), 2010:2). The vision considers education as a potent instrument for human development and thus plans to improve on education curricula with emphasis on ICTs and focused skills acquisition and development. There are 29 National Technical Working Groups (NTWGs) responsible for the realization of NV20:2020, two of which are Education and Information and Communications Technologies (ICTs).

For Nigeria to be counted among the first 20 economies in the world which translate to a Knowledge Economy (KE), the government, organizations and the citizenry must profusely utilize knowledge for greater economic, social and personal development. For effective acquisition, utilization, sharing, creating and recycling of knowledge, the role of ICTs cannot be overemphasized. Thus, knowledge and ICTs are the essential drivers in a Knowledge Economy (Krubu \& Krubu, 2010; Krubu, 2011).
Given the overriding importance of ICT within the nexus of higher education and the thrust of human capital development initiatives in Nigeria, the doctoral research was quite apt in addressing the information behaviour of undergraduates using Kuhlthau's Information Search Process (ISP) model $(2004,2008)$ and the Association of College Research Libraries (ACRL) (2011, 2012) information literacy competencies to investigate the information needs of Nigerian undergraduates in terms of their academic work and everyday life; the information resources and infrastructure available to undergraduates; the information seeking processes of Nigerian undergraduates; and the barriers that undergraduates experience in their information seeking.

A key theme that emerged across the quantitative and qualitative data gathered is what this paper seeks to reveal; it has to do with the nuances of individual lecturers in the process of teaching and learning, and how it impacts on students' information seeking process and creativity.

\section{The concept of information behavior}

In the words of Wilson (2000:49), information behavior is "the totality of human behavior in relation to sources and channels of information, including both active and passive information seeking and information use". The author added that in the event of seeking information, "the individual may interact with manual information systems (such as a newspaper or a library) or with computer-based systems (such as the World Wide Web)". Information behavior refers to how people interact with information; the interaction is often triggered by needs which must be met 
through the various information sources available. Such information sources may range from people to print and online media.

Information need is the conscious awareness of a gap, fanned by the volition to seek meaning in order to fill the gap and become knowing. The conscious effort to acquire information in response to a need or gap in one's knowledge is information seeking (Case, 2006:5; Krubu, 2015). Put differently, it is a conscious and constructive effort to derive the benefit of undistorted meaning from information for the purpose of knowledge acquisition and extension (Kuhlthau, 1991:361). This process requires information handling skills, also referred to as information literacy skills.

\section{Information literacy}

Information literacy is the ability to recognize an information need, efficiently access information sources and evaluate information in a bid to close the gap in information and knowledge. This ability is a set of skills that is needed in the $21^{\text {st }}$-century workplace. The copiousness of information in a technologically inclined $21^{\text {st }}$ century requires attendant skills and ability to efficiently utilize information. These set of skills called information literacy skills are an inevitable and ubiquitous requirement for undergraduates in all fields of endeavor.

The Association of College Research Libraries (2011, 2012) has spelled out five information literacy standards as follows:

An information literate individual is able to:
- Determine the nature and extent of information needed.

- Access and gather the needed information effectively and efficiently.

- Evaluate and critique information and its sources.

- Understand the economic, legal, and social issues surrounding the use of information, and access and use information ethically and legally, either as an individual or a member of a group.

- Understand that information literacy is an on-going process and uses a variety of methods and emerging technologies for keeping abreast of trends in the field.

In Nigeria, studies by Baro and Fyneman (2009); Issa, Amusan and Umma (2009); Abubakar and Isyaku (2012); Adetimirin (2012); and Ukpebor and Emojorho (2012) reveal that the information literacy levels of Nigerian undergraduates are insufficient, even though some students have acquired a certain level of information literacy, including technological skills as well as investigative and critical thinking. Therefore, it may be implied that the type of information literacy education offered in the Nigerian universities and how the existing curricula is administered may be responsible for the poor information handling skills of students, as it has been established by King (2007) and MohdSaad's (2008) in their doctoral research works in South Africa and Malaysia respectively that information literacy education enhances students' information handling skills and academic achievement. 


\section{Kuhlthau's information seeking process} (ISP) model

Kuhlthau studied the learning processes of students in her high school library for her doctoral dissertation, and the endeavor formed the basis for the ISP model. She observed the students for 14 years from high school into university. The results were reported in her 1993 doctoral dissertation and book (1993) along with several articles shortly thereafter.

Kuhlthau's ISP model which has its roots in both information science and constructivist cognitive learning presents two unique features of "uncertainty" and "Zone of Intervention". In the field of Library and Information Science, Kuhlthau's model is considered to be seminal as it addresses information seeking by taking into consideration the cognitive and affective facets of information seeking which have created a common language for researchers.

In addressing the challenges of "seeking meaning" and "sense-making" in the $21^{\text {st }}$ century, Kuhlthau (2008:68) re-emphasizes the fact that:

the ISP model reveals a process in which a person is seeking meaning in the course of seeking information. The model clearly reveals the link between information seeking behavior and the impact of information. In fact, from the user's perspective, the two are inseparably connected.

The ISP model in figure 1 articulates a holistic standpoint of information seeking from the user's perspective in seven stages (Kuhlthau, 2008:67):
- Initiation: this is when a person first becomes conscious of a gap in knowledge or understanding during which the feeling of uncertainty is quite evident.

- Selection: at this stage, a general problem is identified, and the initial uncertainty often declines due to some sense of confidence and a readiness to begin information search.

- Exploration: in the exploration stage, a volume of inconsistent information is encountered. Such information may be overwhelming and incompatible with the topic, hence, the person's level of confusion and uncertainty increases and low confidence level sets in.

- Formulation: formulation of focus is when confidence begins to increase and uncertainty gives way consequent upon a focused perspective.

- Collection: this stage portrays some level of certainty based on focused perspective and hence deep involvement.

- Presentation: at the completion of the search, there is a new understanding which informs learning, sharing and communicating with others.

- Assessment: A positive and conclusive information search gives a sense of accomplishment and increases selfawareness while it is contrary for an information search that is not conclusive. 
Nuances of individual lecturers and its impact on students' information

behaviour and creativity

\begin{tabular}{|c|c|c|c|c|c|c|c|}
\hline \multicolumn{8}{|c|}{ Model of the Information Search Process } \\
\hline & Initiation & Selection & Exploration & Formulation & Collection & Presentation & Assessment \\
\hline $\begin{array}{l}\text { Feelings } \\
\text { (Affective) }\end{array}$ & Uncertainty & Optimism & $\begin{array}{l}\text { Confusion } \\
\text { Frustration } \\
\text { Doubt }\end{array}$ & Clarity & $\begin{array}{l}\text { Sense of direction / } \\
\text { Confidence }\end{array}$ & $\begin{array}{l}\text { Satisfaction or } \\
\text { Disappointment }\end{array}$ & $\begin{array}{l}\text { Sense of } \\
\text { accomplish- } \\
\text { ment }\end{array}$ \\
\hline Thoughts & vague & 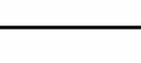 & $\longrightarrow$ & focused & & & Increased \\
\hline $\begin{array}{l}\text { Actions } \\
\text { (Phvsical) }\end{array}$ & seeking & $\begin{array}{l}\text { relevant } \\
\text { Exploring }\end{array}$ & information & seeking & $\begin{array}{c}\text { pertinent } \\
\text { Documenting }\end{array}$ & information & \\
\hline
\end{tabular}

Figure 1: Information Search Process (Kuhlthau, 2004:82)

The ISP model as a process of knowledge articulation with varied cognitive and affective processes is relevant to the study of information behavior irrespective of the information environment, whether print or online media. According to Kuhlthau (2004, 2008), the main inhibitors of information seeking process are a lack of time, poorly designed assignment and confusion of roles, while the enablers are the constructivist view of learning, team approach to teaching, competence in designing process assignments and commitment to developing information literacy.

\section{Blooms taxonomy}

Bloom's Taxonomy revised by Churches (2009) examines the cognitive domain and categorizes thinking order and skills to assist instructors to design class activities and learning outcomes. Bloom's taxonomy is a continuum from Lower Order Thinking Skills (LOTS) to Higher Order Thinking Skills (HOTS) (Churches, 2009:5) (Figure 2). For example, a user must, first of all, remember a concept to understand it, and also a concept can only be applied if understood and remembered. The LOTS is about knowledge acquisition, interpretation, summarizing, inferring, describing, and so on while HOTS involve analyzing, judging and producing. However, Bloom's Taxonomy is not an exclusive layer of the thinking process. At the university level, assignments should be tailored in such a way that it encourages critical thinking, evaluation, and creativity, among others.

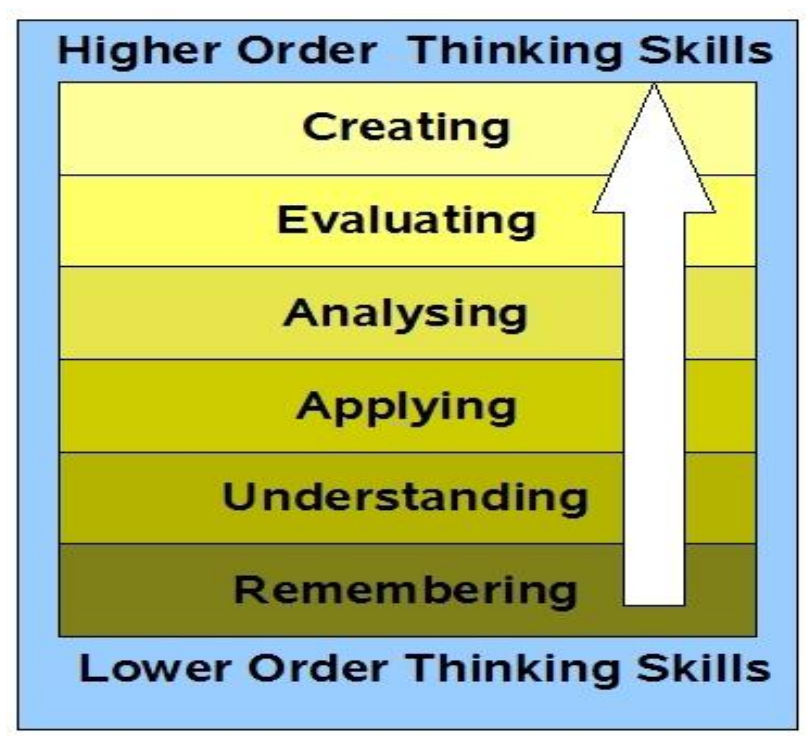

Figure 2: Blooms revised taxonomy by Churches (2009:5) 


\section{Methodology}

The data gathering technique that brought forth the theme that emerged which this paper explicates is two aspects of the qualitative research - dialogue journaling and large group discussions.

\section{Dialogue Journaling}

Dialogue journaling as a procedural tool was adopted for interacting with participants by way of peering into their thoughts, feelings, and actions during their assignment. Dialogue journaling is a written discourse or dialogue between two or more persons in exchange of experiences, ideas or reflections (HaynesMays, Peltier-Glaze \& Broussard, 2011; Alsaleem, 2013). Typically, it involves interactions between the instructor and the students, employed as a literacy strategy at all educational levels to meet diverse educational and social needs. The dialogue journal could be a log, notebook or an electronic journal that aids interaction.

Dialogue journaling with the participants was mainly on WhatsApp messenger, a crossplatform smartphone messenger service that enables online users to send and receive instant messages such a text, audio, and video. According to Bouhnik and Deshen (2014:217), WhatsApp groups can be employed as follows: communicating with students; nurturing the social atmosphere; creating dialogue and encouraging sharing among students; and as a learning platform.

With the support and cooperation of the lecturer who administers Basic Petroleum Geology (PNG 315), the researcher was able to interact with 77 students on this assignment via WhatsApp. The students were in seven groups (Groups A, B, C, D, E, F and G) with eleven students per group and each group had its own assignment under the themes indicated as follows:

a. Group A- Earth Structure; Depositional Basins; Post-Depositional Processes

b. Group B- Petroleum Traps

c. Group C- Earth Structure; Depositional Basins; Post-Depositional Processes

d. Group D- Rocks, Geological Considerations, and Engineering Practices

e. Group E- Petroleum Traps

f. Group F- Earth Structure; Depositional Basins; Post-Depositional Processes

g. Group G- Rocks, Geological Considerations, and Engineering Practices

A textbook titled Basic Petroleum Geology by Peter Link was used for the assignment. Each group was given certain chapter(s) to read, summarize and present in the form of a research report.

Each assignment group formed its own WhatsApp platform; the lecturer and researcher were present on all seven platforms. The interaction between the students, lecturer, and researcher were intensive for seven days, usually from 7 am till about $10 \mathrm{pm}$; that is, students could interact from when they woke up till it was their bed time.

\section{Large Group Discussions (LGDs)}

Focus Group Discussions (FGDs) is "a way of collecting qualitative data, which- 


\section{behaviour and creativity}

essentially - involves engaging a small number of people in an informal group discussion (or discussions), focused on a particular topic or set of issues" (Wilkinson, 2004:177); a simulation of everyday realism. Discussants should be 5 to 10 people per group, but $6-8$ is preferred, and the environment should be conducive; a circle or conference seating (Krueger, 2002; Wilkinson, 2004).

Rather than a Focus Group Discussions (FGDs), a Large Group Discussion (LGDs) held. The change in plans was occasioned by conditions such as venue and time that were not favorable for the FGDs. The LGDs involved 15 students in third-year Petroleum Engineering Department who were part of the dialogue journaling exercise.

The LGDs explored students' range of views and experiences that could not be statistically captured in the quantitative data gathered.

\section{Findings and discussions}

This section explicates the key findings from the dialogue journals and the large group discussions that reveal the nuances of individual lecturers and the impact of students' information behavior and creativity.

\section{Findings from the dialogue journals}

The essence of the journaling exercise with the students was to understand how they go through their assignments; their thoughts, feelings, and actions as explained in Kuhlthau's ISP model, during the various stages of assignment writing. Kuhlthau's ISP model explicates the process of seeking meaning while seeking information (Kuhlthau, 2008:68).
It reveals information seeking from the users' perspective in seven stages (Kuhlthau, 2008:67): initiation, selection, exploration, formulation, collection, presentation, and assessment.

However, from the analysis of the WhatsApp journals with the third year students of Petroleum Engineering Department on the PNG 315 assignment, it was glaring that they did not necessarily experience Kuhlthau's ISP. In the first instance, the assignment did not include a research problem even though students submitted a research report as required by the course lecturer.

The students had only one week to do the group assignment, which did not give enough room for them to meet and work together as a team. This aspect seems to undermine the pedagogy of group assignment. Lack of time is identified by Kuhthau (2004) as one of the inhibitors of information seeking process. Ideally, there should be enough time to give room for intense interactions and exchange.

Information seeking involves some level of cognitive aptitude. Kuhlthau's ISP model gives some latitude for cognitive expression which the dialogue journaling was able to capture during the supposed or what should have been the exploration and collection stages of the students' information seeking process.

Exploration: in the exploration stage, a volume of inconsistent information is encountered. Such information may be overwhelming and incompatible with the topic, hence, the person's level of confusion and uncertainty increases and low confidence level sets in. 
The students did not necessarily go through the exploration stage because they were fed with information to work with; they were required to read and summarize certain chapters of the Basic Petroleum Geology textbook by Peter Link. Put differently, there was no research problem to explore. Hence, they did not experience an intense information search, even though they were asked to seek additional information. A high level of confusion and uncertainty attributed to the exploration phase (Kuhlthau, 2004, 2008, 20012) of the ISP model and low confidence levels were not experienced by the students. True to the words of Kulthau (2004), the poorly designed assignment inhibited the information search process of the students. The same topics/themes could have been given to students without asking them to use a particular source thereby narrowing their search or rather preventing them from searching for information.

Collection: this stage portrays some level of certainty based on focused perspective and hence deep involvement.

This was not evident in the journals as students had no research problem to solve; hence there was no "focused perspective". They were only required to read, understand and explain which was implied in a statement by their lecturer during the chat in Group F:

I expect that your report is supposed to teach me. So whether I know the terms or not is not important. You should understand those terms and explain them to me. This is why I said that if the constraint on pages is too tight, I must be informed first before any additional pages are included. I have extended the maximum number of pages for two groups because of this. So, research on those terms and come up with good explanations on them.

The level of assignment encourages lower order thinking according to Blooms Taxonomy (Churches, 2009) because it addressed reading, understanding, remembering and explaining only.

\section{Findings from the large group discussion}

A theme that featured in the large group discussion was the nuances of individual lecturers in the process of teaching and learning. Lecturers seem to expect students to conform to their own thinking; this negatively impacts on students' information seeking process and creativity and impedes information literacy acquisition. It appears there is no standard policy in place to address how students are evaluated in their tests or examinations, which by extension also affect the conduct and assessment of assignments. Consequently, the mode of assessment is at the discretion of the lecturers. For instance, students expressed their concerns as follows:

S11: I remember when we were in 100 level (year one) when we were taking a number of general courses together in the college, the lecturers usually share the exam scripts among themselves. They would have written the 
expected answers (marking scheme) and the person marking will mark exactly according to the marking scheme

Researcher: Please could you give an example?

S11: Okay. For instance, if you read the course, understand and put it down in your own words, you may not do well with someone who gave the exact words back to the lecturer. It is very rigid.

S10: The problem is that $70 \%$ of us cram. For example, if you see a very intelligent student who is in the second class upper range, ask him a question from what he was taught in 100 level, no, let's say 200 level, he may not remember, because all we do is cram.

A lecturer will tell you this is what I want and this is the approach you should use. For example in mathematics, you may think a particular approach is better and you are going to arrive at the same answer but the Lecturer will say "this is what I want". There is a lecturer in my department, Dr.....for example if he says define a computer. For me, I prefer to define it using my own words but for him, he wants some kind of sequence and words. And if you don't conform you will score " 0 ". So no room for my personal understanding and language.
S12: It all depends on the Lecturer, in my department, some lecturers expect you to explain in your own words, you need not give them what they gave you but they need keywords from you. For example, I was asked a question by my lecturer "what is a sediment", he was looking for the keywords "weathered materials", and soon as I used the keywords, the lecturer said I got it. But there are some other lecturers, for instance, the one who taught us today, he told us that if we want to pass his course that we have to use the words, the exact words that he gave us.

It is impressive to note that some lecturers allow for students' individuality in expression. However, for the other lecturers who do not allow for individual language and creativity in the course of assessing students' academic work as detailed in the discussion, constitute a serious impediment to the possibilities for high academic attainments on the part of the students. What this translates to is that students would have to go through one assignment/exam or the other, and possibly be penalized for any omission or commission as set by each lecturer, to acquire the skills set required to navigate through the personal nuances of the respective lecturers to "please" them.

Besides, demanding that students should regurgitate their (lecturers') exact words and penalize those who worked contrarily is a way of 'killing' and undermining the creativity and individuality of certain students. Under such conditions, information literacy acquisition is 
reduced to a "dream to come". While it is true that certain keywords or phrases are very important in elucidating some facts and knowledge, it is also important that students are allowed to lend their voices as well.

That being said, students in a particular department did mention that one of their lecturers employs Learning Management System in their class interactions. While narrating this to the researcher, the atmosphere in the course of discussion was charged with so much joy and youthful energy and it was obvious that for that particular class, students always looked forward to it.

S09: We (in computer science department) have a new lecturer who studied in Canada who introduced new social media stuff to us. So we have our course notes, assignments, and test questions online.

Researcher: Tell me more about the learning platform?

S09: I don't know but it is a student-lecturer platform, like a classroom. He created a classroom for us where we interact, get messages and share insights. So we get our notes before the class.

The implication is that the university not officially using a Learning Management System (LMS), that is no policy on the use of LMS. Apart from the students, this shortfall was mentioned by a staff in the ICT department (the Web developer), some lecturers observed by the researcher. Therefore, they miss out on the Web 2.0 learners support features which are very crucial in teaching and learning in the $21^{\text {st }}$ century. Such features include discussion forums, file exchange, emails, online journals, notes, real-time chat, videos, individual grades and progress reports (Stockley \& Olsson, 2013).

\section{Implications for theory and research}

Kuhlthau ISP model is the primary model used as a lens to examine how students search and use information in their academic tasks. The model could not be applied in its entirety to the study's particular context of teaching and learning because in the nature of the assignments, elements of a guided approach to learning, under which Kuhlthau's ISP may be employed, are missing. Therefore, alternative theories, such as Theory of Change (Quality Education in Developing Countries (QEDC), 2008) could explicate the type of intervention that would enhance students' learning. While the theory and practice of critical education by Shor (2012) can give insights into tested teaching and learning methods that enhance education through critical and democratic pedagogy for social change, which translates to national development as Nigeria works towards Vision 20:2020.

The journaling also provided a rare opportunity to both students and lecturer alike to interact during the assignments. Students were able to chat freely with their lecturer on social media for the first time. The experience set a pace and standard for the parties involved especially the lecturers and the students. Both parties informed the researcher that the journaling afforded them a glimpse into the challenges that students face in the process of writing their assignments, especially in the case of group 


\section{behaviour and creativity}

assignments when they need to meet, discuss, brainstorm and garner their thoughts in order to fulfill the purpose of the assignment.

One of the implications of the research for practice is the need for lecturers to employ Web 2.0 tools in their teaching and learning based on the testimony of one of the lecturers who took part in the journaling experience. Beyond that, deploying a Learning Management System (LMS) with learner support features will enhance the teaching and learning experience of both lecturers and students alike.

\section{Conclusion and recommendations}

The paper has explicated a critical theme on the information behavior of undergraduates in the world of Web 2.0 using a specialized university in Nigeria. The theme centered on the nuances of individual lecturer and its effect on students' information behavior and creativity. The theme expounded emerged from the qualitative aspect of the research endeavor, namely: dialogue journaling and large group discussions. The assignment given to the students was poorly designed, a lower order thinking skills (LOTS) assignment based on Blooms' taxonomy (Churches, 2009). It would have served the students better if it encouraged higher order thinking skills (HOTS) such as critical thinking, evaluation, and creativity. Due to the nature of the assignment given, the student did not seem to conform to the cognitive aspect of Kuhlthau's ISP model because the task given was not challenging, hence their ISP was inhibited.

Consequently, alternative theories have been suggested: Theory of Change (Quality
Education in Developing Countries (QEDC), 2008) and the theory and practice of critical education by Shor (2012)

Some lecturers expect students to rehearse what they have given them word for word thereby inhibiting their information search process and impeding their information literacy skills acquisition, while some other lecturers give the latitude for self-expression, individuality, and creativity - by extension - enabling information literacy skills acquisition through freedom of information search and freedom of expression. These imply a lack of uniform standard and policy on teaching and learning methods and must be looked into by the university.

\section{References}

Abubakar, U. A. \& Isyaku, A. A. (2012). Teaching Information Literacy Skills in Nigerian Universities: Whose Responsibility? Journal of Research in Education and Society, 3(2): 33-42.

Adetimirin, A.E. (2012). ICT literacy among undergraduates in Nigerian universities. Educ Inf Technol, (2012)17: 381-397.

Alsaleem, B.I. (2013). The Effect of "WhatsApp" Electronic Dialogue Journaling on Improving Writing Vocabulary Word Choice and Voice of EFL Undergraduate Saudi Students. Arab World English Journal, 4(3), 213225. Online \{Available http://www.awej.org/images/AllIssues/ Volume4/Volume4Number3Sept2013/1 8.pdf [Accessed May, 15, 2015] 
Nuances of individual lecturers and its impact on students' information

behaviour and creativity

Association of College and Research Libraries (2011). Standards for libraries in higher education. Online \{Available <http://www.ala.org/acrl/sites/ala.org.ac rl/files/content/standards/slhe.pdf> [Accessed May 17, 2013]

Association of College and Research Libraries/American Library Association (2012). Information Literacy Standards for Science and Engineering/Technology. The ALA/ACRL/STS Task Force on Information Literacy for Science and Technology.

Online $\{$ Available $\}<$ http://www.ala.org/acrl/st andards/infolitscitech> [Accessed October 25, 2012]

Baro, E.E. \& Fyneman, B. (2009). Information literacy among undergraduate students in Niger Delta University. The Electronic Library, 27 (4): 659-675.

Bouhnik, D. \& Deshen, M. (2014). WhatsApp goes to school: Mobile instant messaging between teachers and students. Journal of Information Technology Education: Research, 13: 217-231. Online \{Available <http://www.jite.org/documents/Vol13/ JITEv13ResearchP217-

231Bouhnik0601.pdf> [Accessed May, 15, 2015]

Case, D.O. (2006). Information behaviour. In Annual Review of Information Science and Technolog. Edited by Cronin, B. 40(1):293-372. Medford, NJ: Informattion Today.
Churches, A. (2009). Bloom's Digital Taxonomy. Educational Origami.

Haynes-Mays, I., Peltier-Glaze, B. \& Broussard, S.L. (2011). The Status of Dialogue Journal Writing as a Methodology for the Literacy and Language Development of African American Students. ECI Interdisciplinary journal for legal and social policy. 1(1). Online \{Available\} $<$ http://ecipublications.org/ijlsp/vol1/iss $\underline{1 / 3}>$ [Accessed May, 15, 2015]

Issa, A.O., Amusan, B. \& Umma, D.D. (2009). Effects of Information Literacy Skills on the Use of E-Library Resources among Students of the University of Ilorin, Kwara State, Nigeria. Library Philosophy and Practice, February 2009 Edition. Online \{Available <http://www.Webpages.uidaho.edu/ m bolin/issa-blessing-daura.htm $>$

[Accessed March 7, 2013]

King, L. (2007). Information literacy of incoming undergraduate Arts students at the University of the Western Cape: assessment of competencies and proficiencies. Ph.D. Thesis. Bellville: University of the Western Cape.

Krubu, S.G \& Krubu, D.E. (2010). Meeting Nigeria's $21^{\text {st }}$ Century Educational Goals by a Vision of Learning through Technology. Studies in Education.11 (1): 55-68.

Krubu, D.E. (2011) Towards Building Learning Organizations: The Impact of Motivation on Knowledge Sharing, 
Nuances of individual lecturers and its impact on students' information

behaviour and creativity

IRCAB Journal of Social and

Management Sciences, 1(1): 64-70.

Krueger, R.A. (2002). Designing and Conducting Focus Group Interviews. Focus group interviewing. Online \{Available\}

http://www.eiu.edu/ ihec/Krueger-

FocusGroupInterviews.pdf? > [Accessed May 3, 2014]

Kuhlthau, C. C. (1991). Inside the search process: information seeking from the users perspective. Journal of the American Society for Information Science and Technology. 42(5): 361371.

Kuhlthau, C. C. (1993). Seeking meaning: a process approach to library and information services. Norwood, NJ, Ablex Publishing.

Kuhlthau, C. C. (2004). Seeking meaning: A process approach to library and information services. $2^{\text {nd }}$ edition. Westport, CT: Libraries Unlimited.

Kuhlthau, C.C. (2008). From Information to Meaning: Confronting Challenges of the Twenty-first Century. Libri, 58: 6673. Online \{Available <http://ocacinformationliteracy.pbwork s.com/w/file/fetch/30835148/Kuhlthau. FromInformationToMeaning.pdf $>[$ Acc essed October 3, 2012]

MohdSaad, M.S. (2008). Ascertaining Information Literacy and Information Seeking Behaviour of Students Conducting Final Year Project. Ph.D. Dissertation, University of Malaysia.
Online

\{Available

$<$ http://dspace.fsktm.um.edu.my/handle /1812/137> [Accessed April 27, 2012].

National Planning Commission (2010). Nigeria vision 20:2020: abridged version. Online $\quad$ Available <http://www.npc.gov.ng/vault/Abridge d_Version_of_Vision2020.pdf > [Accessed October 18, 2015]

Quality Education in Developing Countries Initiative (QECD) (2008). The Quality Education in Developing Countries Initiative Grantmaking Strategy $(Q E D C) . \quad$ Online $\quad$ Available http://www.hewlett.org/uploads/files/Q EDCGrantmakingStrategy_Final.pdf [Accessed April 22, 2015]

Shor, I. (2012). Empowering Education: Critical Teaching for Social Change. Kindle edition. University of Chicago Press.

Stockley, S. \& Olsson, J. (2013). Learning Management System Presentation. Online $\quad$ Available http://www.authorstream.com/Presentat ion/jennyolsson-378811-learningmanagement-system-presentationeducation-ppt-powerpoint/> [Accessed January 13, 2014].

Ukpebor, C.O. \& Emojorho, D. (2012). Information Literacy Skills: A Survey of the Transition of Students from Secondary to University Education in Edo State, Nigeria. Library Philosophy and Practice, Paper 824:1-8. Online \{Available\} 
Nuances of individual lecturers and its impact on students' information behaviour and creativity

$<\underline{\text { http://digitalcommons.unl.edu/cgi/vie }}$

wcontent.cgi?article $=2073 \&$ context $=$ lib philprac> [Accessed March 7, 2013]

Wilkinson, S. (2004). Focus group research. In Qualitative Research: Theory, Method, and Practice. Edited by Silverman, D. (pp. 177-199). Thousand Oaks, CA: Sage
Wilson, T.D. (2000). Human Information Behaviour. Special Issue on Information Behaviour Research. 3(3): 49-55.Online \{Available\} $<$ http://ptarpp2.uitm.edu.my/ptarpprack /silibus/is772/HumanInfoBehavior.pdf $>$ [Accessed September 5, 2015]

About the Author: Dr. Dorcas Ejemeh Krubu, is a Lecturer in the Department of Library and Information Science, Ambrose Alli University, Ekpoma, Edo State, Nigeria. She can be contacted on dkrubu@gmail.com 